\title{
Детектирование ТГц волн в кристаллах GaSe:S с помощью фемтосекундных лазерных импульсов на длине волны 1550 нм
}

\author{
О.Н. Шевченко ${ }^{1,2}$, Н.А. Николаев ${ }^{1,2}$, К.А. Кох ${ }^{2,3}$ \\ ${ }^{1}$ Институт автоматики и электрометрии СО РАН, Новосибирск, 630090, просп. Академика \\ Коптюга 1 \\ ${ }^{2}$ Новосибирский государственныій университет, Новосибирск, 630090, ул. Пирогова 1 \\ ${ }^{3}$ Институт геологии и минералогии СО РАН, Новосибирск, 630090, просп. Академика Коптюга 3 \\ тел: +7(953)8669924, эл. почта: shewchenko.lesia@yandex.ru
}

DOI 10.34077/RCSP2021-41

Особый интерес для инженерии устройств прикладной оптики в ТГц диапазоне частот представляет разработка эффективных детекторов излучения методами нелинейной оптики. Цель данной работы заключается в исследовании одного из таких детекторов - кристаллов $\mathrm{Ga}_{50 \%} \mathrm{Se}_{50-\mathrm{-} \%} \mathrm{~S}_{\mathrm{x}} \%$, где х принимает значения: $0,1.5,6,8,11$, на эффективность детектирования ТГц волн в телекоммуникационном диапазоне (1550 нм).

Образцы для исследований были изготовлены в ИГиМ СО РАН. Атомное вхождение серы определялось методом ЭДС СЭМ.

Также, на базе ИАиЭ СО РАН был собран ТГц спектрометр с генерацией лазерного излучения на длине волны 1550 нм. В работе проведено сравнение эффективности детектирования терагерцового поля в вышеупомянутом ряде кристаллов и приведено сравнение с наиболее распространенным детектором для длин волн 1550 нм - кристаллом GaAs.

Предварительные результаты демонстрируют, что наибольшей чувствительностью обладает кристалл детектора GaSe с процентным содержанием серы в количестве 6\%, а также падение чувствительности детектора на основе $\mathrm{Ga}_{50 \%} \mathrm{Se}_{44 \%} \mathrm{~S}_{6 \%}$ относительно GaAs на $25 \%$ с учетом потерь на переотражение. Впервые произведена оценка электрооптического коэффициента для кристаллов $\mathrm{GaSe}$ (для длин волн 1550 нм), для наиболее чувствительного кристалла $r_{33}=2,36$ пм/В. 